\title{
IDENTIFYING ENGLISH LANGUAGE NEEDS OF RELIGIOUS GUIDES AT THE GENERAL PRESIDENCY OF THE GRAND MOSQUE AND PROPHET'S MOSQUE
}

\author{
Mahmoud Aljadani \\ English Language Institute, King Abdulariz. University, Saudi Arabia \\ maljadani0047@stu.kau.edu.sa \\ Turki Alsolami \\ English Language Institute, King Abdulariz University, Saudi Arabia \\ Faculty of applied Studies, King Abdulariz University, Saudi Arabia \\ tgalsolami@kau.edu.sa
}

\begin{abstract}
This study aims at identifying English language needs for religious guides at The General Presidency of The Grand Mosque and Prophet's Mosque. This study adopted a quantitative approach methodology using needs analysis questionnaire. The quantitative data collection instrument was a questionnaire with (51) participants. SPSS was used as the quantitative data analysis method. Findings showed that listening and speaking were the most important skills, and reading was moderately important, while writing is not important at all. Also, English is greatly rated as a tool to effectively perform their tasks in term of preaching and advising guests and pilgrims. Difficulties are embodied in lacking English language, accents, and proper religious expressions and vocabulary. This study highlights an urgent need for English for Religious Purposes. The study proposes a general guideline for a course design framework based on participants' needs.
\end{abstract}

Keywords: English for religious purposes, ESP, needs analysis, religious guides, Saudi Arabia

\section{INTROUDCTION}

he Grand Mosque of Makkah receives millions of Muslims every year. Most of these pilgrims are not Arabic speakers, and resides either to native language or English

coming from Asian countries, European countries, African countries, south and

North American countries. Since English language is a global language, the level of people providing services to pilgrim should have a good command of English to communicate and respond to pilgrims. Therefore, the role of English in a religious site visited by millions from all over the world is important. Religious guides (RGs) at The Grand Mosque need to have a higher level of English to convey clear messages and to understand interlocutors whenever English is being used. They need not only a general course in English but also, they need also training on religious English as most of the communication with pilgrims is based mostly on religious matters. In return, this will improve the quality of services that are being provided to pilgrims and visitors of The Grand Mosque. Therefore, to understand the English language needs for RGs is essentially vital to plan a tailored program that can enhance the level of communication between pilgrims and RGs. 


\section{Research Objectives}

This study aims to identify the English language needs for RGs at The Grand Mosque of Makkah. Additionally, it also aims to propose general guidelines for a proper English language course that suits and fulfils their actual communicative needs with non-Arabic speaking guests and visitors based on their reported English Language needs.

\section{Research Questions}

This overarching questions for this study are:

1- To what extent do RGs view the importance of English in their workplace?

2- What are the English communication skills required RGs in the holy mosque? And what kind of linguistic activities are needed in their workplace?

3- What are the perceptions about religious English needs in the pilgrims' services?

\section{LITERATURE REVIEW}

\section{Definition of Needs Analysis (NA)}

NA is a core process to be conducted before designing any language courses of any kind. Brown (2016) maintains that the relationship between NA and English for Specific Purposes (ESP) is intertwined, and it would hard for ESP to exist without it (p. 5). NA has been defined by many researchers in the field of ESP. One of the most widely used definitions is by Brown (2009). Brown (2009) defines NA as "the systematic collection and analysis of all information necessary for defining a defensible curriculum” (p. 269). From Brown's perspective, is a process of gathering data about learners' needs which lead to a defendable curriculum. This is a common understanding among many of the other definitions of NA available in the literature.

\section{Approaches of $\mathbf{N A}$}

There are different approaches to formulate NA's items of data collection tool based on the assumptions of course stakeholders who intend to investigate and being investigated: 1) Target Situation Analysis 2) Present Situation Analysis 3) Learning needs analysis 4) Register, Discourse and Genre Analysis. This section elaborates them briefly.

\section{Target Situation Analysis}

Chambers (1980) coined the term Target Situation Analysis (TSA) inspired by Munby's (1981) Communication Needs Processor (CNP). Dudley-Evans, et al., (1998) define TSA as the certain level of linguistic competence is essential for learners to function in target situation. Munby (1981) developed CNP's theoretical framework which is recognized as Needs Processor 
(NP). NA contains categories and sub-categories which include skills and sub-skills that are required to achieve fair-enough functioning in target situation.

\section{Present Situation Analysis}

Present Situation Analysis (PSA) was introduced by Richterich and Chancerel (1980). According to Dudley-Evans, et al., (1998), PSA refers to decision made at the beginning of a course about what learners are good at and what needs to improve for a successful starting.

\section{Learning Needs Analysis}

Learning Needs Analysis (LNA) or Pedagogic Needs Analysis (PNA) was first presented by West (1994). LNA or PNA are broad concepts that includes: Deficiency Analysis, Strategy or Learning Analysis, and Means Analysis. These will be explained in the coming sections.

\section{Deficiency Analysis}

Deficiency Analysis (DA) identifies learners' PST and TSA “lacks, wants, and needs" (Hutchinson \& Waters, 1987; Jordan, 1997; West, 1994). Therefore, DA investigates and analyses data about what learners' lack, want, and need to start a language program and finish successfully. DA is more comprehensive than PSA and TSA.

\section{Strategy or Learning Analysis}

Hutchinson and Walters (1987) and West (1998) indicate that Strategies or Learning Analysis (SLA) refers to techniques that learners recruit to learn a new language. Learners only can access this type of NA as it felt and subjective needs (Jordan, 1997). Learners should learn activities, tasks, and skills that help them achieve TSA, and that can be supported by motivating learners and help them to progress (Dudley-Evans, et al., 1998). SLA helps class to move toward learner-centred-approach (Hutchinson \& Walters, 1987). Therefore, it helps, supports and motivates learners to learn satisfyingly and efficiently.

\section{Means Analysis}

Means Analysis (MA) scrutinizes external elements of learning process "classroom ambience" which was ignored in Munby's (1981) CNP framework, and it provides supportive date about learning environment which assists to develop a more comprehensive syllable (Dudley-Evans et al., 1998). MA provides information like common culture, facilities, teacher's profiles, etc could aid to design a course that suits certain ambience (Swales, 1990). 


\section{Register, Discourse, and Genre Analysis}

\section{Register Analysis}

Register Analysis (RA) also called "lexicostatistics" (Dudley-Evans et al., 1998). Robinson (1991, p 23) defines RA as “frequency analysis". West (1998) reports that RA has more emphasis on grammatical and lexical level. Thus, RA studies how certain grammatical structures and lexis are frequent and do not go beyond sentence level. This supports ESP designers to focus on these frequencies as they more probably occur in specific conversations of contexts (DudleyEvans et al., 1998). Hutchinson and Walter (1987) claim RA assists ESP course designers make instructional contents more appropriate to learners' needs.

\section{Discourse Analysis}

Due to the harsh critiques to RA, Discourse Analysis (DA), also called "rhetorical or textual analysis, has emerged because RA does not go further than sentence level (West, 1994), illustrative not expressive (Robinson, 1991), and lack authenticity (Dudley-Evans et al., 1998). Hutchinson and Water (1987) DA studies the combination of sentences and how they are connected, which focuses on the communicative principles rather than structural. DA assists learners to connect utterances and sentences more appropriately which helps the rhythms and flow of the target language.

\section{Genre Analysis}

Bhatia (2015) defines Genre Analysis (GA) as the study of how language is used within particular contexts, settings and events; professional, academic, or social events. For example, in sport match event where people watching and analysing that event their language structures and lexis differ from their speech if they attend other social events like visiting a patient at hospital. GA goes two levels deeper than RA and one level than DA which provides learners with the broadest umbrella of linguistic variations: expressions, structures, and lexis.

\section{NA of English for Religious Purposes:}

English for religious purposes, particularly Islam, has been a new branch in ESP with a growing number of studies is the Muslim world (Abudhahir, et.al, 2014). The term "English for Religious Purposes", has been recently used and other terms that were found in the literature were Islamic English or English for Islamic studies. These studies investigated the needs of English based on perceptions of English language, Skills needed and challenges that are faced 
at various levels of education and occupations with a particularly emphasis on topics related to Islam.

English, as a global Language, is a demand in many countries and hold a high value among speakers around the world, including Muslims for various reasons such as studying, working and travelling. Studies in the Muslim context indicate that many Muslims view English as an important language and have high motivation to learn it. Muslims, like other people of nations and faiths have hopes, aspiration, and love to explore the world, and mastering English Language can create opportunities for them, particularly among Non-English-speaking Muslims. The literature reveals that there have been a number of NA studies for ESP in Muslim contexts for various needs including, tourism, police, Islamic studies students etc. (e.g. Abdellah \& Ibrahim, 2013; Abudhahir and Ali,2018; Aldohon, 2014; Al-Gorashi, 1988; Alhamami, 2020; Alhuqbani, 2008; Juhary, 2013; Muhammad \& Abdul Raof, 2020), including English for religious purposes, which is the focus here.

As for the needs of English in Muslim countries, a few NA studies were conducted in Muslim contexts for English for religious, or as some studies coined it Islamic purposes. In Indonesia, Sahiba and Mirza (2019) investigated students' beliefs about English language needs at IAIN Palangka Raya using a survey, and 110 students completed the survey. Findings indicated that the majority of students needs English as a tool to broadcasting and communicating Islam to the world. In the same vein, Abudhahir and Ali (2018), surveyed 30 Malaysian students of Islamic studies on their view of English, most needed skills and materials to be included in a proposed English for Islamic studies course. Findings indicate that majority of students highly students the importance of English, and rated speaking as the most needed skill as they want to become Islamic preachers. As for materials, participants indicate that Islamic related materials with more focus on role-playing activities. Tarihoran and Rahimah (2019) voice their concerns on the lack of materials for in The Muslim world and indicate that the failure or success of teaching English in Islamic culture is largely dependent on the availability of appropriate syllabus and materials design.

In Pakistan, Ahmad and Khushi (2014), conducted a semi-structured interview with 30 Muslim religious scholars to explore their needs of reading skills needs in religious texts. Participants believe that religious texts are complex, and that the translated English vocabularies are difficult to understand. Other reading skills difficulties were also reported, such as inferring meaning from a text, skimming and scanning and comprehending complex sentence structure. 
The study recommended that must exposed to various authentic religious genre texts such as Quran verses translated in English, interpretations, commentaries, sayings of the prophet Muhammed.

Saudi Arabia is considered the heart of all Muslim world for having the most two religious sites, Makkah and Medina, and Muslims come in millions for Hajj and Umrah every year. However, despite the importance of Hajj and Umrah services is growing, there is a very limited studies conducted on the use of English for religious purposes in Hajj and Umrah. Samer (2014) investigated spoken English needs of 11 Hajj volunteers from Riyadh Education. Results indicate that there is a need for spoken English course to help them to communicate effectively with pilgrims to ease the stressful communication between the volunteer and pilgrims due to the lack of English. Abdellah and Ibrahim (2013) conducted a mixed method study to investigate English language needs for 100 Hajj Guides at the Mosque of Prophet Muhammed in Madinah city using a questionnaire, proficiency test and unstructured interviews. Findings showed that participants need listening and speaking are the most important skills. It recommended a course design guideline. A large number of the participants indicate that they need English for occupational purposes such understanding and giving safety instructions, describing the characteristics of a medical emergency and sending emergency messages. The study concluded with a list of recommendation which include an urgent for developing an ESP courses for Hajj guides that focus more on productive skills (listening and speaking). In addition, materials for this course should focus on the vocational nature of Hajj guides in Medina with emphasis on giving direction, making oneself understood, and attending Medina visitors' needs.

Despite the limited number of studies that studied the English needs at various Muslim contexts, Makkah RGs, the most visited religious site by all Muslims around the world for Hajj and Umrah, has not been investigated. There is an urgent and important need to investigate the religious needs as part of developing the services offered to All Hajj and Umrah visitors. In addition, this is a gap in the literature on English for religious purposes that this study intends to fill.

\section{METHDOLOGY}

This section discusses methodology of this study: context, participants, research paradigms, research designs, data collection methods, data analysis methods, and study evaluation. These elements are elaborated and reflected empirically on the study. 
Aljadani and Alsolami, Indentifying English Language Needs...

\section{Research Design}

This study adopts a quantitative research design using a questionnaire to collect from a large population information related to their level of English, perceptions, and challenges with English language.

\section{Context, Sampling and Participants}

Participants of this study are working in the "Presidency of The Holy Grand Mosque Affairs" in the city of Makkah, Saudi Arabia. It is the most sacred place for all Muslims around the world. One of the services offered, is religious guidance where pilgrim have religious questions or inquiry about right ritual practices and RGs respond them either by visiting their office in The Grand Mosque or inside The Grand Mosque while they are doing their rituals. For this study 51 RGs completed an online questionnaire. A convenient sampling strategy was applied to recruit participants for this study from a large population of RGs.

Data Collection Instruments and procedures

\section{Questionnaire}

This study adopted and modified an existing questionnaire that was developed by a Saudi Researcher (Alhuqbani, 2008). Alhuqbani (2008) designed semi-structured questionnaire to identifying English language needs of some security sectors in Saudi Arabia. Alhaqbani's questionnaire contains questions related to general information, received training programs, types of needed skills, activities and language, importance of English in workplace and personal life, linguistic difficulties, and recommendations. Types and structures of questions were "yes" and "no" questions, Likert scale, open-ended questions exploring IDs of security officers and recommendations. Some of these items were modified, replaced, and deleted to properly investigate English language of RGs. Additionally, an optional open-ended was devised to each section of questionnaire to get deeper understanding. The original questionnaire was written in English, therefore, this study questionnaire was translated into Arabic and sent to an Arabic language editor specialist for face validity.

The questioner was sent to all RGs working in the Grand Mosque whom were about 140 RGs. Only 51 RGs filled out the online questionnaire.

\section{Data Analysis Procedures}


SPSS software was used to generate descriptive data that include means, and percentages. In addition, a thematic analysis was performed on the qualitative part of the open-ended questions part of the questionnaire.

\section{FINDINGS DISCUSSION}

\section{Quantitative Findings}

The quantitative data collection instrument was a questionnaire which contained 68 items tackled many issues relevant to ESP for the employees of General Presidency of The Grand Mosque affairs. Total participants are 51 out of 140 employees. These quantitative findings were uploaded to elicit percentages " $\%$ " and frequencies " $p$ " as presented in Table (1-11) followed with explanations.

Need of English at Work

Table 1 Needs of English at work

\begin{tabular}{|c|c|c|c|c|}
\hline \multirow{3}{*}{ NO. } & \multicolumn{4}{|c|}{ Is there a need for English at Work? } \\
\hline & \multicolumn{2}{|c|}{ Yes } & \multicolumn{2}{|c|}{ No } \\
\hline & $p$ & $\%$ & $p$ & $\%$ \\
\hline 1. & 50 & $98 \%$ & 1 & $2 \%$ \\
\hline
\end{tabular}

In Table 1, Participants were asked about the need of English at their work. This question received "yes" from 50 participants and only one of the total population answered " $n o^{\text {", which }}$ is $2 \%$. This result indicates that there is a huge need for English language in their work.

In the open-ended question for participants to give reason for "Why English is needed in their work", participants revealed that English is important because it is being used by many pilgrims, and it is also needed as the medium of communication with non-Arabic speaking and for advising pilgrims. The following quotes were taken from some of the participants' answers to this question.

"English is an International language and becomes more and more common inside The Grand Mosque”

"Many of non-Arabic Muslims can speak. English well but not Arabic"

"Through my years of serving in The Grand Mosque, I need English because many nonArabic committing religious wrongdoings, so we need to advise them" 


\section{English Usage Frequency at Work:}

Table 2. Frequency of English

\begin{tabular}{|c|c|c|c|c|c|c|c|c|c|}
\hline \multicolumn{8}{|c|}{ Level of English usage frequency at Work } \\
\hline \multicolumn{2}{|c|}{ Always } & \multicolumn{2}{|c|}{ Usually } & \multicolumn{2}{c|}{ Sometimes } & \multicolumn{2}{c|}{ Rarely } & \multicolumn{2}{c|}{ Never } \\
\hline$p$ & $\%$ & $p$ & $\%$ & $p$ & $\%$ & $p$ & $\%$ & $p$ & $\%$ \\
\hline 8 & $15.7 \%$ & 4 & $7.8 \%$ & 34 & $66.7 \%$ & 3 & $5.9 \%$ & 2 & $3.9 \%$ \\
\hline
\end{tabular}

In Table 2, Participants were also asked in this section about the frequency of using English at work. "Sometimes" received the highest responses by participants which indicate that English Is not highly used in their work, followed by "always" and "usually". These results combined represent 46 participants, which can clearly indicate a considerate level of frequency needed to use English.

\section{Levels of English Language Proficiency}

Table 3. Participants' Levels of English Proficiency

\begin{tabular}{|c|c|c|c|c|c|c|c|c|c|c|c|c|c|}
\hline \multirow{3}{*}{$\begin{array}{l}\mathrm{N} \\
\mathrm{O}\end{array}$} & \multirow{3}{*}{$\begin{array}{l}\text { Overall } \\
\text { Language, } \\
\text { Skills \& } \\
\text { Subskills }\end{array}$} & \multicolumn{12}{|c|}{ Level of Proficiency } \\
\hline & & \multicolumn{2}{|c|}{ Excellent } & \multicolumn{2}{|c|}{$\begin{array}{l}\text { Very } \\
\text { good }\end{array}$} & \multicolumn{2}{|c|}{ Good } & \multicolumn{2}{|c|}{ Acceptable } & \multicolumn{2}{|c|}{ Weak } & \multicolumn{2}{|c|}{ Very weak } \\
\hline & & $P$ & $\%$ & $P$ & $\%$ & $P$ & $\%$ & $P$ & $\%$ & $p$ & $\%$ & $p$ & $\%$ \\
\hline 1. & Overall & 2 & $\begin{array}{l}3.9 \\
\%\end{array}$ & 3 & $\begin{array}{l}5.9 \\
\%\end{array}$ & 8 & $\begin{array}{l}15.7 \\
\%\end{array}$ & 12 & $23.5 \%$ & 7 & $\begin{array}{l}13,7 \\
\%\end{array}$ & 19 & $37 \%$ \\
\hline 2. & Listening & 2 & $\begin{array}{l}3.9 \\
\%\end{array}$ & 4 & $\begin{array}{l}7.8 \\
\%\end{array}$ & 11 & $\begin{array}{l}21.6 \\
\%\end{array}$ & 7 & $13.7 \%$ & 7 & $\begin{array}{l}13.7 \\
\%\end{array}$ & 20 & $39.2 \%$ \\
\hline 3. & Speaking & 2 & $\begin{array}{l}3.9 \\
\%\end{array}$ & 1 & $2 \%$ & 9 & $\begin{array}{l}17.6 \\
\%\end{array}$ & 13 & $25.5 \%$ & 4 & $\begin{array}{l}7.8 \\
\%\end{array}$ & 22 & $43 \%$ \\
\hline 4. & Reading & 0 & 00.0 & 9 & $\begin{array}{l}17.6 \\
\%\end{array}$ & 2 & $3.9 \%$ & 14 & $27.5 \%$ & 5 & $\begin{array}{l}9.8 \\
\%\end{array}$ & 21 & $41.2 \%$ \\
\hline 5. & Writing & 1 & $2 \%$ & 5 & $\begin{array}{l}9.8 \\
\%\end{array}$ & 7 & $\begin{array}{l}13.7 \\
\%\end{array}$ & 10 & $19.6 \%$ & 3 & $\begin{array}{l}5.9 \\
\%\end{array}$ & 25 & $49 \%$ \\
\hline
\end{tabular}




\begin{tabular}{|l|l|l|l|l|l|l|l|l|l|l|l|l|l|}
\hline 6. & Grammar & 0 & 00.0 & 3 & $\begin{array}{l}5.9 \\
\%\end{array}$ & 8 & $\begin{array}{l}15.7 \\
\%\end{array}$ & 14 & $27.5 \%$ & 12 & $\begin{array}{l}23.5 \\
\%\end{array}$ & 14 & $27.5 \%$ \\
\hline 7. & Vocabulary & 0 & 00.0 & 2 & $\begin{array}{l}3.9 \\
\%\end{array}$ & 7 & $\begin{array}{l}13.7 \\
\%\end{array}$ & 20 & $39.2 \%$ & 8 & $\begin{array}{l}15.7 \\
\%\end{array}$ & 14 & $27.5 \%$ \\
\hline
\end{tabular}

In Table 3, participants were asked about their level of English in all skills. The results show that over $50 \%$ of the participants indicate that their "overall" English proficiency is either "weak" or "very weak". While the others about 50\% was distributed between "acceptable", "good", "very good", and "excellent". The majority of participants as shown in the table, the number of participants who choose excellent and very good are very low.

In listening, 55\% of participants agreed that their level is either "weak" or "very weak". However, the rest 45\% showed "acceptable", "good", "very good", and "excellent". In speaking, 51\% of the population agreed that their speaking ability is either "weak" or "very weak". While less $48 \%$ indicate "acceptable", "good", "very good", and "excellent".

In reading, over $51 \%$ of the participants indicate that their reading skill is either "weak" or "very weak". While the rest of participants are allocated on "acceptable", "good", "very good", and "excellent". In writing, over 55\% of community of the study reported that their writing skill is either "weak" or "very weak". Nevertheless, the remnant fractioned over "acceptable", "good", "very good", "excellent".

In grammar, over 51\% reported that "weak" or "very weak", while less than $49 \%$ allocated on "acceptable", "good", "very good", and "excellent". In vocabulary, around 41\% reported their levels are either "weak" or "very weak". Furthermore, around 39\% showed that their level of vocabulary is "acceptable". The other fraction is allotted on "good", "very good", and "excellent".

The results show that despite the importance of English as mentioned previously, the overall of their indicated levels on many of the skills is unsatisfactory for an industry that requires a high command of English. It is clear from the table that most of the participants indicate a weakness in language skills. 
Table 4. Importance of English

\begin{tabular}{|c|c|c|c|c|c|c|c|c|c|c|c|}
\hline \multirow{3}{*}{ NO } & \multirow{3}{*}{$\begin{array}{l}\text { English } \\
\text { Language } \\
\text { Skills }\end{array}$} & \multicolumn{10}{|c|}{ Level of Importance } \\
\hline & & \multicolumn{2}{|c|}{ Very important } & \multicolumn{2}{|c|}{ Important } & \multicolumn{2}{|c|}{ Neutral } & \multicolumn{2}{|c|}{ Less important } & \multicolumn{2}{|c|}{ Not important } \\
\hline & & $p$ & $\%$ & $p$ & $\%$ & $p$ & $\%$ & $p$ & $\%$ & $p$ & $\%$ \\
\hline 1. & Listening & 39 & $76.5 \%$ & 11 & $21.6 \%$ & - & - & - & - & 1 & $2 \%$ \\
\hline 2. & Speaking & 40 & $78.4 \%$ & 9 & $17.6 \%$ & - & - & 1 & $2 \%$ & 1 & $2 \%$ \\
\hline 3. & Reading & 7 & $13.7 \%$ & 26 & $51.1 \%$ & - & - & 16 & $31.4 \%$ & 2 & $3.9 \%$ \\
\hline 4. & Writing & 7 & 13.7 & 9 & 17.6 & - & - & 12 & $23.5 \%$ & 23 & $45.1 \%$ \\
\hline 5. & Grammar & 29 & $56.9 \%$ & 8 & $15.7 \%$ & - & - & 11 & $21.6 \%$ & 3 & $5.9 \%$ \\
\hline 6. & Vocabulary & 35 & $68.6 \%$ & 9 & 17.6 & - & - & 6 & $11.8 \%$ & 1 & $2 \%$ \\
\hline
\end{tabular}

As shown in Table 4, participants were asked to rate the importance of English in all skills. The table illustrates that listening, speaking, grammar and vocabulary rated as "very important" skills with percentages $76.5 \%, 78.4 \%, 56.9 \%$, and $68.6 \%$ respectively. Furthermore, reading was not received as very important, however, it was indicated that it is an important skill by $51 \%$ of the participants. Writing was reported as "less important" or "not important" skill at all. It can be implied from these results that Participants are mostly focusing on communicative skills where Listening and Speaking were of the highest percentage.

\section{The Importance of English by Skill}

In order to improve our understanding the specific needs of each skill, in the questionnaire participants were asked about their needs for each skill separately. Participants were asked to rate the importance of items of each skills, followed by an open-ended question where they can write any other reasons for the importance of those skills in their work. 
Table 5. Importance of Listening

\begin{tabular}{|c|c|c|c|c|c|c|c|c|c|c|c|}
\hline \multirow{3}{*}{$\mathrm{NO}$} & \multirow{3}{*}{ Items } & \multicolumn{10}{|c|}{ Importance of Listening } \\
\hline & & \multicolumn{2}{|c|}{$\begin{array}{l}\text { Very } \\
\text { important }\end{array}$} & \multicolumn{2}{|c|}{ Important } & \multicolumn{2}{|c|}{ Neutral } & \multicolumn{2}{|c|}{$\begin{array}{l}\text { Less } \\
\text { important }\end{array}$} & \multicolumn{2}{|c|}{$\begin{array}{l}\text { Not } \\
\text { important }\end{array}$} \\
\hline & & $p$ & $\%$ & $p$ & $\%$ & $p$ & $\%$ & $p$ & $\%$ & $p$ & $\%$ \\
\hline 1. & $\begin{array}{l}\text { To understand religious } \\
\text { utterances, words and terms } \\
\text { related to Hajj and Umra. }\end{array}$ & 45 & $88.2 \%$ & 5 & $9.8 \%$ & - & - & - & - & 1 & $2 \%$ \\
\hline 2. & $\begin{array}{l}\text { To understand words and } \\
\text { texts of general English. }\end{array}$ & 41 & $80.2 \%$ & 8 & $15.7 \%$ & - & - & 1 & $2 \%$ & 1 & $2 \%$ \\
\hline 3. & $\begin{array}{l}\text { To understand visitors and } \\
\text { guests of The Grand Mosque } \\
\text { who are non-Arabic speakers }\end{array}$ & 44 & $86.3 \%$ & 6 & 11.8 & - & - & - & - & 1 & $2 \%$ \\
\hline 4. & $\begin{array}{l}\text { To understand religious } \\
\text { lectures and workshops } \\
\text { related to Hajj and Umra }\end{array}$ & 19 & $37,3 \%$ & 17 & $33.3 \%$ & - & - & 12 & $23.5 \%$ & 3 & $5.9 \%$ \\
\hline 5. & $\begin{array}{l}\text { To understand general } \\
\text { questions and inquiries raised } \\
\text { by guests and visitors of The } \\
\text { Grand Mosque }\end{array}$ & 44 & $86.3 \%$ & 6 & $11.8 \%$ & - & - & 1 & $2 \%$ & 1 & $2 \%$ \\
\hline
\end{tabular}

As shown in Table 5, participants were asked to rate the importance of the Listening skill in five statements. As shown in table (7), the highest reason for the importance of listening skill which received $88.2 \%$ was "to understand religious texts, words and terms related to Hajj and Omra", followed by two reasons which scored the same percentage $86.3 \%$ "to understand general questions and inquiries raised by guests and visitors of The Grand Mosque" and "to understand visitors and guests of The Grand who are non-Arabic speakers". Another reason which scored by $80.2 \%$ was "to understand words and texts of general English". The least reason which significantly received low rates 37.3\% was "to understand religious lectures and workshops related to Haij and Umra". These percentages indicate that, participants view Listening skill as highly important for religious and work-related communication.

In the optional open-ended questions section, a very limited number of participants shared their reasons for the importance of listening skill which was mostly related to understanding pilgrims English, as one of the participants mentioned "To understand questions raised by English speakers". 
Table 6. Importance of Speaking

\begin{tabular}{|c|c|c|c|c|c|c|c|c|c|c|c|}
\hline \multirow{3}{*}{ NO } & \multirow{3}{*}{ Items } & \multicolumn{10}{|c|}{ Importance of Speaking } \\
\hline & & \multicolumn{2}{|c|}{$\begin{array}{l}\text { Very } \\
\text { important }\end{array}$} & \multicolumn{2}{|c|}{ Important } & \multicolumn{2}{|c|}{ Neutral } & \multicolumn{2}{|c|}{$\begin{array}{l}\text { Less } \\
\text { important }\end{array}$} & \multicolumn{2}{|c|}{$\begin{array}{l}\text { Not } \\
\text { important }\end{array}$} \\
\hline & & $P$ & $\%$ & $p$ & $\%$ & $p$ & $\%$ & $p$ & $\%$ & $p$ & $\%$ \\
\hline 1. & $\begin{array}{l}\text { To use words and terms } \\
\text { related to Haji and } \\
\text { Umra in conversations. }\end{array}$ & 43 & $84.3 \%$ & 6 & $11.8 \%$ & - & - & 1 & $2 \%$ & 1 & $2 \%$ \\
\hline 2. & $\begin{array}{l}\text { To use words and texts } \\
\text { of general English in } \\
\text { conversations. }\end{array}$ & 38 & $74.5 \%$ & 8 & $15.7 \%$ & - & - & 4 & $7.6 \%$ & 1 & $2 \%$ \\
\hline 3. & $\begin{array}{l}\text { To give clear } \\
\text { information and } \\
\text { instructions to non- } \\
\text { Arabic speakers of } \\
\text { guests and visitors of } \\
\text { The Grand Mosque. }\end{array}$ & 42 & $82.4 \%$ & 7 & $13.7 \%$ & - & - & 1 & $2 \%$ & 1 & $2 \%$ \\
\hline 4. & $\begin{array}{l}\text { To talk about religious } \\
\text { topics and concepts } \\
\text { related to Hajj and } \\
\text { Umra }\end{array}$ & 42 & $82.4 \%$ & 8 & $15.7 \%$ & - & - & - & - & 1 & $2 \%$ \\
\hline
\end{tabular}

In Table 6 as shown, participants were asked to rate the importance of Listening skill in four statements. As shown in table (8), the highest reason for the importance of speaking skill which received $84.3 \%$ was "To use words and terms related to Haij and Umra in conversations", followed by two reasons which scored the same percentage $82.4 \%$; they are: "To give clear information and instructions to non-A rabic speakers of guests and visitors of The Grand Mosque." and "To talk about religious topics and concepts related to Haij and Umra. The least reason which received lower rates yet not very significantly different from other reasons was "To use words and texts of general English in conversations" where $74.5 \%$ of the participants view it as very important.

In the optional open-ended questions section, a number of RGs shared their reasons for the importance of speaking skill which was mostly related to understanding advising and preaching pilgrims about religious matters, as indicated in the following two quotes: 
"To advise wrongdoers using English"

"To preach to the righteous way of the Prophet Mohammed and his companions"

Table 7. Importance of Reading

\begin{tabular}{|c|c|c|c|c|c|c|c|c|c|c|c|}
\hline \multirow{3}{*}{$\mathrm{NO}$} & \multirow{3}{*}{ Items } & \multicolumn{10}{|c|}{ Importance of Reading } \\
\hline & & \multicolumn{2}{|c|}{$\begin{array}{l}\text { Very } \\
\text { important }\end{array}$} & \multicolumn{2}{|c|}{ Important } & \multicolumn{2}{|c|}{ Neutral } & \multicolumn{2}{|c|}{$\begin{array}{l}\text { Less } \\
\text { important }\end{array}$} & \multicolumn{2}{|c|}{$\begin{array}{l}\text { Not } \\
\text { important }\end{array}$} \\
\hline & & $p$ & $\%$ & $p$ & $\%$ & $p$ & $\%$ & $p$ & $\%$ & $p$ & $\%$ \\
\hline 1. & $\begin{array}{l}\text { To read and understand religious } \\
\text { words and terms related to Hajj } \\
\text { and Umra. }\end{array}$ & 32 & $62.7 \%$ & 12 & $23.5 \%$ & - & - & 5 & $9.8 \%$ & 2 & $3.9 \%$ \\
\hline 2. & $\begin{array}{l}\text { To read and understand words } \\
\text { and texts of general English. }\end{array}$ & 30 & $58.8 \%$ & 14 & $27.5 \%$ & - & - & 3 & 5.9 & 2 & $3.9 \%$ \\
\hline 3. & $\begin{array}{l}\text { To read understand religious } \\
\text { topics and texts related to Hajj } \\
\text { and Umra }\end{array}$ & 32 & $62.7 \%$ & 14 & $27.5 \%$ & - & - & 3 & $5.9 \%$ & 2 & $3.9 \%$ \\
\hline
\end{tabular}

In Table 7, participants were asked to rate the importance of Reading skill in three statements. As shown in table (9), the highest two reasons which scored the same percentage $62.7 \%$ were "To read understand religious topics and texts related to Haij and Umra" and "To read and understand religious words and terms related to Haij and Umra". However, the first statement was also reported by $27.5 \%$ of the participants which makes it higher when we combine "very important" and "important" together.

The least reason which received lower rates yet not very significantly different from other reasons was "To read and understand words and texts of general English" where 58.8\% of the participants view it as very important.

In the optional open-ended questions section, a number of participants shared their reasons for the importance of reading skill which was mostly related to reading pilgrims' IDs and understanding religious pamphlets, as reported in the following quotes

"To assist lost people through reading their addresses in their IDS"

"To read religious books which are written in English and make sure that they are aligned with the right Islam". 
Table 8. Importance of Writing

\begin{tabular}{|c|c|c|c|c|c|c|c|c|c|c|c|}
\hline \multirow{3}{*}{ No } & \multirow{3}{*}{ Items } & \multicolumn{10}{|c|}{ Importance of Writing } \\
\hline & & \multicolumn{2}{|c|}{$\begin{array}{l}\text { Very } \\
\text { important }\end{array}$} & \multicolumn{2}{|c|}{ Important } & \multicolumn{2}{|c|}{ Neutral } & \multicolumn{2}{|c|}{ Less important } & \multicolumn{2}{|c|}{$\begin{array}{l}\text { Not } \\
\text { important }\end{array}$} \\
\hline & & $p$ & $\%$ & $p$ & $\%$ & $p$ & $\%$ & $p$ & $\%$ & $p$ & $\%$ \\
\hline 1. & $\begin{array}{l}\text { To write religious } \\
\text { words and terms } \\
\text { related to Hajj and } \\
\text { Umra. }\end{array}$ & 13 & $25.5 \%$ & 9 & $17.9 \%$ & - & - & 3 & $5.9 \%$ & 26 & $51 \%$ \\
\hline 2. & $\begin{array}{l}\text { To write incident } \\
\text { reports. }\end{array}$ & 10 & $19.6 \%$ & 8 & $15.9 \%$ & - & - & 14 & $27.5 \%$ & 19 & $37.3 \%$ \\
\hline 3. & $\begin{array}{l}\text { To write sentences } \\
\text { and short articles. }\end{array}$ & 12 & $23.5 \%$ & 6 & $11.8 \%$ & - & - & 7 & $13.7 \%$ & 26 & $51 \%$ \\
\hline
\end{tabular}

Participants were asked to rate the importance of Writing skill in three statements as shown in Table 8. The two reasons which scored the same percentage $51 \%$ were "To write religious words and terms related to Haij and Umra." and "To write sentences and short articles.", and they were considered by the participants as "Not important". The results indicate a low number of participants who view writing skill as either "very important or "important". As shown in table (10), writing skill, in contrast to other previous skills, was not of importance to the participants. As for the statement "To write incident reports", which received $37.3 \%$, if we combine the score of "important $27.5 \%$, it becomes the highest rated statement of a total of $64.8 \%$, followed by a combined statement of "To write sentences and short articles" $64.7 \%$ are closely related.

\section{Difficulties Faced by RGs in English:}

Table 9. Difficulties of English

\begin{tabular}{|l|l|l|l|l|l|l|}
\hline \multirow{2}{*}{ NO } & \multirow{2}{*}{ Difficulties } & \multicolumn{4}{|l|}{ Level of Agreement } \\
\cline { 3 - 7 } & $\begin{array}{l}\text { Strongly } \\
\text { agree }\end{array}$ & Agree & Neutral & Disagree & $\begin{array}{l}\text { Strongly } \\
\text { disagree }\end{array}$ \\
\hline
\end{tabular}




\begin{tabular}{|l|l|l|l|l|l|l|l|l|l|l|l|}
\hline 1. & $\begin{array}{l}\text { Difficulty in following } \\
\text { English conversations of } \\
\text { natural } \\
\text { speed }\end{array}$ & 32 & $62.7 \%$ & 11 & $21.6 \%$ & 5 & $9.8 \%$ & 2 & $3.9 \%$ & 1 & $2 \%$ \\
\hline 2. & $\begin{array}{l}\text { Difficulty in understanding } \\
\text { different accents }\end{array}$ & 33 & $64.7 \%$ & 6 & $11.8 \%$ & 8 & $15.7 \%$ & 3 & $5.9 \%$ & 1 & $2 \%$ \\
\hline 3. & $\begin{array}{l}\text { Difficulty in understanding } \\
\text { all that is said in English }\end{array}$ & 31 & $60.8 \%$ & 11 & $21.6 \%$ & 8 & $15.7 \%$ & 1 & $2 \%$ & 2 & $3.9 \%$ \\
\hline 4. & $\begin{array}{l}\text { Difficulty in responding to } \\
\text { all that is said in English }\end{array}$ & 33 & $64.7 \%$ & 6 & $11.8 \%$ & 9 & $17.6 \%$ & 2 & $3.9 \%$ & 1 & $2 \%$ \\
\hline 5. & $\begin{array}{l}\text { Difficulties in using } \\
\text { English due to different } \\
\text { cultures }\end{array}$ & 36 & $70.6 \%$ & 5 & $9.8 \%$ & 7 & $13.7 \%$ & 2 & $3.9 \%$ & 1 & $2 \%$ \\
\hline
\end{tabular}

As shown in Table 9, participants were asked to rate their level of agreement or disagreement with a number of difficulties that are faced in their workplace related to English. As shown in table (11), there was a number of difficulties that scored high percentage by the participants. The highest reported statement was "Difficulties in using English due to different cultures", which scored $70.6 \%$. The second two difficulties that were equally reported with a percentage of $64.7 \%$ were "Difficulty in understanding different accents" and "Difficulty in responding to all that is said in English".

In this optional open-ended questionnaire, a number of GRs shared similar difficulties mentioned in the questionnaire, as shown in the following quotes:

"As an English speaker who speaks English perfectly, I always face problems in understanding articulations of English of Indians, Pakistanis, Indonesians and other Asians"

"I face problems in giving directions and describing object and do my best using my body language"

\section{Level of Importance of English at Work \& Personal Life:}

Table 10. Importance of English at Work and Personal life

\begin{tabular}{|l|l|l|l|l|l|l|l|l|l|l|l|l|}
\hline & \multicolumn{8}{|l|}{} & \multicolumn{8}{l|}{ Level of Importance at Work \& Personal Life } \\
\hline \multirow{3}{*}{ NO } & \multirow{3}{*}{ Items } & $\begin{array}{l}\text { Very } \\
\text { important }\end{array}$ & Important & Neutral & $\begin{array}{l}\text { Less } \\
\text { important }\end{array}$ & \multicolumn{2}{|l|}{ Not important } \\
\cline { 3 - 10 } & & $p$ & $\%$ & $p$ & $\%$ & $p$ & $\%$ & $p$ & $\%$ & $p$ & $\%$ \\
\hline
\end{tabular}




\begin{tabular}{|c|c|c|c|c|c|c|c|c|c|c|c|}
\hline 1. & $\begin{array}{l}\text { Performing my Job } \\
\text { effectively }\end{array}$ & 40 & $78.4 \%$ & 10 & $19.6 \%$ & - & - & - & - & 1 & $2 \%$ \\
\hline 2. & Passing training courses & 22 & $43.1 \%$ & 14 & $27.5 \%$ & - & - & 5 & $9.8 \%$ & 10 & $19.6 \%$ \\
\hline 3. & $\begin{array}{l}\text { Passing professional } \\
\text { exams and evaluations }\end{array}$ & 17 & $33.3 \%$ & 18 & $35.3 \%$ & - & - & 6 & $11.8 \%$ & 10 & $19.6 \%$ \\
\hline 4. & $\begin{array}{l}\text { Increasing knowledge in } \\
\text { my } \\
\text { Field of specialization and } \\
\text { work }\end{array}$ & 25 & $49 \%$ & 20 & $39.2 \%$ & - & - & 5 & $9.8 \%$ & 1 & $2 \%$ \\
\hline 5. & $\begin{array}{l}\text { Promoting to a higher } \\
\text { position }\end{array}$ & 18 & $35 \%$ & 17 & $33.3 \%$ & - & - & 5 & $9.8 \%$ & 11 & $21.6 \%$ \\
\hline 6. & Increasing stipends & 31 & $60 \%$ & 14 & $27.5 \%$ & - & - & 2 & $3.9 \%$ & 4 & $7.8 \%$ \\
\hline 7. & $\begin{array}{l}\text { Rewarding a scholarship } \\
\text { in an English-speaking } \\
\text { country }\end{array}$ & 31 & $60 \%$ & 14 & $27.5 \%$ & - & - & 2 & $3.9 \%$ & 4 & $7.8 \%$ \\
\hline 8. & $\begin{array}{l}\text { To speak with non-Arabic } \\
\text { Speakers in various topics } \\
\text { of life }\end{array}$ & 36 & $70.6 \%$ & 7 & $13.7 \%$ & - & - & 4 & $7.8 \%$ & 4 & $7.8 \%$ \\
\hline 9. & $\begin{array}{l}\text { Using the internet to } \\
\text { search the } \\
\text { English websites }\end{array}$ & 34 & $66.7 \%$ & 9 & $17.6 \%$ & - & - & 3 & 5.9 & 5 & $9.8 \%$ \\
\hline
\end{tabular}

In assessing RGs, the importance of English to their personal lives, they were asked to indicate the level of importance of English in nine statements. As shown in Table 10, the highest rate statement by participants was "Performing my Job effectively" which scored 78.4\%, and we combine the results of expression "agree" $19.6 \%$, the results increased to $98 \%$. When applying the same to other results the second highest statement is "Increasing knowledge in my field of specialization and work", with its combined result $88 \%$. Other results which scored equally in combination of "very important" and "important" were the statements: "Increasing stipends" and "Rewarding a scholarship in an English-speaking country" which were 87.5. In addition, the statements "To speak with non-Arabic Speakers in various topics of life" and "Using the internet to search the English websites" scored 84.3\%. All these results indicate that participants highly value the importance of English for the various reasons as reported in the questionnaire.

\section{Activities needed in English}

Table 11. Activities Needed in English 


\begin{tabular}{|c|c|c|c|c|c|c|c|c|c|c|c|}
\hline \multirow{3}{*}{ No } & \multirow{3}{*}{ Activities needed in English } & \multicolumn{10}{|c|}{ Level of Agreement } \\
\hline & & \multicolumn{2}{|c|}{$\begin{array}{l}\text { Strongly } \\
\text { agree }\end{array}$} & \multicolumn{2}{|c|}{ Agree } & \multicolumn{2}{|c|}{ Neutral } & \multicolumn{2}{|c|}{ Disagree } & \multicolumn{2}{|c|}{$\begin{array}{l}\text { Strongly } \\
\text { disagree }\end{array}$} \\
\hline & & $p$ & $\%$ & $p$ & $\%$ & $p$ & $\%$ & $p$ & 5 & $P$ & $\%$ \\
\hline 1. & $\begin{array}{l}\text { Eliciting information of identities } \\
\text { of non-Arabic speakers }\end{array}$ & 38 & $74.5 \%$ & 10 & $19.6 \%$ & - & - & 2 & $3.9 \%$ & 1 & $2 \%$ \\
\hline 2. & $\begin{array}{l}\text { Discussing religious issues related } \\
\text { to performing rituals }\end{array}$ & 45 & $88.2 \%$ & 4 & $7.8 \%$ & 1 & $2 \%$ & - & - & 1 & $2 \%$ \\
\hline 3. & $\begin{array}{l}\text { Giving clear directions of inquired } \\
\text { locations }\end{array}$ & 44 & $86.3 \%$ & 8 & $11.8 \%$ & - & - & - & - & 1 & $2 \%$ \\
\hline 4. & Investigating incidents & 16 & $31.4 \%$ & 12 & $23.5 \%$ & 16 & $31.4 \%$ & 6 & $11.8 \%$ & 1 & $2 \%$ \\
\hline 5. & Providing helps and assistances & 47 & $92.2 \%$ & 3 & $5.9 \%$ & - & - & - & - & 1 & $2 \%$ \\
\hline 6. & $\begin{array}{l}\text { Inquiring about descriptions of } \\
\text { missing objects, values, and } \\
\text { missing circumstances }\end{array}$ & 44 & $86.3 \%$ & 4 & $7.8 \%$ & 2 & $3.9 \%$ & - & - & 1 & $2 \%$ \\
\hline 7. & $\begin{array}{l}\text { Inquiring about descriptions } \\
\text { missing people }\end{array}$ & 44 & $86.3 \%$ & 4 & $7.8 \%$ & 2 & $3.9 \%$ & - & - & 1 & $2 \%$ \\
\hline 8. & $\begin{array}{l}\text { Collaborating and communicating } \\
\text { with non-Arabic speaking } \\
\text { embassies and consulates' } \\
\text { representatives }\end{array}$ & 43 & $84.3 \%$ & 6 & $11.8 \%$ & 1 & $2 \%$ & - & - & 1 & $2 \%$ \\
\hline
\end{tabular}

Participants, were asked to report their level of agreement or disagreement on the needed activities of English. As shown in Table 11 the highest reported activity was "Providing helps and assistances" which scored $92.2 \%$. The second reported activity was "Discussing religious issues related to performing rituals", which scored $88.2 \%$. The third highly reported activities were "Inquiring about descriptions of missing objects, values, and missing circumstances" and "Inquiring about descriptions missing people". Another high reported activity which scored $84.3 \%$ was "Collaborating and communicating with non-Arabic speaking embassies and consulates' representatives". The activity "Investigating incidents" was significantly reported by the participants which scored $31.4 \%$.

\section{Open-ended questions from the questionnaire}

In the last section of the questionnaire, an open-ended question was given to RGs to provide any suggestion to improve the situation of English language education in their sector. A number of RGs shared their views which indicate the need of English to perform their religious obligations better as shown in the following quotes: 
Aljadani and Alsolami, Indentifying English Language Needs...

"There is an extreme and urgent need to learn English and improve our communication abilities"

"To belp pilgrims clarifying the right way of Islam and Prophet Mohammed peace be upon him, and we should not remain silent because of not knowing English"

"Communicating in English abilities are prime important to start

Dialogue to correct some misunderstood concepts"

The main aim of this study was to identify English language needs of the staff of the Presidency of The Grand Mosque in the holy city of Makkah. The study adopted a quantitative method research design. A questionnaire was filled out by 51 participated in the questionnaire.

Regarding the importance of English to be used in RGs at The Grand Mosque and the reasons for its importance, it is clear that participants reached almost a consensus with 98\% confirming English is needed in their workplace "Holy Mosque", and it is very frequent. This percentage indicates that English is extremely important for RGs, and this is in line with previous studies which indicated the importance of English in professional life (Abdellah \& Ibrahim, 2013; Alhamami, 2020;). Participants seem to highly regarded English as important to their work for various reasons such as a medium of communication to help pilgrims who do not speak Arabic in advising them about places, rituals, and directions around The Grand Mosque. In addition, English is highly regarded because it is also used to preach Non- Arabic Muslim speakers. This highlights the importance of English to deliver the words of Allah to a wider audience and preach non-Arabic speakers of worshipers in the holy cities (Abdellah \& Ibrahim, 2013).

The significant result on the importance of English is aligned with ESP framework that employees, who work in service industries which The Grand Mosque is a part of Hajj and Umra industry of those industries. They need English language to provide services to guests who cannot speak Arabic language (Abdellah \& Ibrahim, 2013; Samer, 2014). Abdellah and Ibrahim (2013), point that it is crucial for Hajj guides to speak English .The Prophet' Mosque visitors are mostly has the same characteristic of visitors of The Grand Mosque because those visitors come to The Grand Mosque for Hajj or Umra, and when they finish, they go to the Prophet Mosque for visitation.

Findings of the questionnaire reveals that the most highly needed English language skills in RGs' jobs are listening and speaking. This is in line with ESP theory that English for Occupational Purposes (EOP) emphasizes more on "listening" and "speaking" as they 
represent the spontaneous communicative skills which enable interlocutors of different native languages negotiate information at workplace successfully. These findings are similar to other studies which were conducted on other Muslim contexts (Abdellah \& Ibrahim, 2013; Sahiba \& Mirza, 2019; Samer, 2014).

Reading skill was also highlighted as an important skill for RGs which was shown in the questionnaire. Participants need reading skills to read and understand the publications written in English which are brought with pilgrims and visitors because most of the time these publications violate religious rules. This is in a line with a previous study (Ahmad \& Khushi, 2014), where reading was found to be an important skills for an Islamic preacher. Their study suggested that reading materials should include authentic Islamic texts to enable the preachers to understand the English translated vocabularies related to religious matters.

One of the research questions of this study was to tackle the issues of difficulties faced by RGs. Findings indicate that one of the major issues for RGs is poor English level. This result was evident in the questionnaire when they were asked to indicate their levels in English. This can be linked to lack of English training courses in their sector which was mentioned by a number of participants. Similar findings were also reported by (Samer, 2014) where due to the low level of the Hajj volunteers, it created a stressful communication between them and the pilgrims.

One of the issues that was reported by a number of participants, particularly with higher level of English, was Pilgrims English accent. They indicate that the accent hinders them from understanding pilgrims' English inquires. Similar finding was found in a previous study (e.g., Samer, 2014). Abdellah and Ibrahim (2013) recommend that accents and pronunciations should be considered in designing a course for Hajj guides in Madinah city.

The importance of English for professional purposes was one of the themes identified in this study. In the questionnaire, the findings indicate that the highest two reasons for the need of English in RGs jobs was to perform their jobs effectively and to increase their knowledge when to deal with non-Arabic speakers. This is can be linked to a religious duty to serve the visitors of The Grand Mosque. Similar findings were voiced other studies in Muslim contexts where they wanted to broadcast and communication English to the world (Abudhahir \& Ali, 2018; Sahiba \& Mirza , 2019; Samer, 2014). It can be argued that some of the tasks particularly asking and responding to inquiries are shared with RGs working at The Grand Mosque, 
however, the nature and types of questions are more complex, religiously focused, and require sometimes a high command of English.

The nature and types of English language activities and tasks for RGs were also explored in this study. The questionnaire results show that English is extremely needed by RGs in preaching and advising, answering inquiries, and giving directions which were the most frequently mentioned situations. In The context of The Grand Mosque, the main tasks of RGs are all about preaching and advising those visitors who are in need. e.g., how to perform certain rituals or advising wrongdoers, giving directions and replying on visitors' inquiries are the key tasks for RGs' jobs. If their English level is not as high as it is expected to be, this as a result will affect their performance. As some previous studies indicated, the nature of activities and materials for Islamic guidance or advising should focus on authentic materials taken from Quran or Prophet Sayings or other religious publication such as commentaries, and the nature of activities should be more communicative e.g., role-playing (Abudhahir \& Ali, 2018; Ahmad \& Khushi, 2014).

\section{CONCLUSION}

This study is of an importance to a sector in Saudi Arabia that serves the pilgrims, and the government has been doing its utmost to provide the best services for the welfare of pilgrims. Participants in this study acknowledge the importance of English language in performing their jobs more effectively. English is not widely spoken among RGs at a level that allow to complex communication situation with English-speaking pilgrims, and it's due to lack of language training in general and a more focused language training on English for religious purposes. Their language needs tend to be more on the use of the language for communication where it is highly needed on speaking and listening skills, which are more related to the nature of jobs when dealing with English-speaking pilgrims. The use of English more needed for guiding, advising and answering pilgrims in various religious matters, which require a tailored English language program that target and reflect the language and situations they are likely to encounter which may including qur'anic verses, hadith, rituals. Therefore, this study offer a broad guideline for an English course for religious purposes that serve the needs for RGs in Makkah and Madinah. 


\section{REFERENCES}

Abdellah, A., \& Ibrahim, M. (2013). Towards developing a language course for Hajj guides in al-madinah al-munawwarah, a needs assessment. International Education Studies, 6(3). https://doi.org/10.5539/ies.v6n3p192

Abudhahir, R. A., Mahdun, M., \& Nor, R. M. (2015). Need Analysis and Material Development in English for Specific Purposes in Relation to English for Islamic Studies. Journal of Management \& Muamalah, 5(2).

Ahmad, N., \& Khushi, Q. (2014). An Analysis of Religious Scholars' Needs for Reading Religious Texts Written in English. Pakistan Journal of Islamic Research, 14(14), 113-121.

Aldohon, H. I. (2014). English for specific purposes (ESP) for Jordanian tourist police in their workplace: Needs and problems. International Education Studies, 7(11). https://doi.org/10.5539/ies.v7n11p56

Al-Gorashi, A. K. (1988). The English communication needs of military cadets in Saudi Arabia as perceived by junior officers in the Saudi Army and air defense [Unpublished doctoral dissertation]. Indiana University.

Alhamami, M. (2020). Language barriers in multilingual Saudi hospitals: Causes, consequences, and solutions. International Journal of Multilingualism, 17(2), 113. https://doi.org/10.1080/14790718.2020.1777134

Alhuqbani, M. B. (2008). Identifying the English Language Needs of Saudi Police Officers. Journal of the Saudi Association of Languages and Translation, 1(2), 55-97.

Bhatia, V. K. (2015). Critical genre analysis. Hermes - Journal of Language and Communication in Business, 54, 9-20. https://doi.org/10.4324/9781315690315

Brown, J. D. (2009). Foreign and second language needs analysis. In M. H. Long, \& C, Doughty (Eds.), The handbook of language teaching (pp. 269-293). Wiley-Blackwell.

Brown, J. D. (2016). Introducing needs analysis and English for specific purposes. Routledge.

Chambers, F. (1980). A re-evaluation of needs analysis in ESP. The ESP Journal, 1(1), 2533. https://doi.org/10.1016/0272-2380(80)90007-4

Dudley-Evans, T., John, M. J., \& John, M. J. (1998). Developments in English for specific purposes: A multi-disciplinary approach. Cambridge University Press.

Hutchinson, T., \& Waters, A. (1987). English for specific purposes. Cambridge University Press.

Jordan, R. R. (1997). English for academic purposes: A guide and resource book for teachers. Cambridge University Press. 
Aljadani and Alsolami, Indentifying English Language Needs...

Juhary, J. B. (2013). Using Military Vocabulary and Concepts for Successful Language Learning at the Defence University. Literacy Information and Computer Education Journal, 4(3).

Muhammad, I., \& Halim Abdul Raof, A. (2019). Assessing the ESP needs of Saudi engineering undergraduates: A diagnostic view. Arab World English Journal, 10(4), 204222. https://doi.org/10.24093/awej/vol10no4.16

Munby, J. (1981). Communicative syllabus design: A sociolinguistic model for designing the content of purposespecific language programmes. Cambridge University Press.

Richterich, R., \& Chancerel, J. (1980). Identifying the needs of adults learning a foreign language. Pergamon Press.

Robinson, R. (1991). ESP Today: A Practitioner's Guide. Hemel Hempstead. Prentice Hall.

Sahiba, A., \& Mirza, A. A. (2019). Investigating students' belief toward the importance of English learning for dakwah activity at IAIN Palangka Raya. In The 3rd INACELT (International Conference on English Language Teaching). Institut Agama Islam Negeri (IAIN) Palangka Raya Indonesia.

Samer, A. K. (2014). Spoken English for Saudi Haij volunteers: A need assessment [Unpublished master's thesis]. Spoken English for Saudi Hajj volunteers: A need assessment.

Sayed Abudhahir, R. A., \& Mohamad Ali, A. (2018). English for Islamic studies: Should I learn English? - From the eyes of Islamic studies students. LSP International Journal, 5(1). https://doi.org/10.11113/lspi.v5n1.65

Swales, J. M. (1990). Discourse analysis in professional contexts. Annual Review of Applied Linguistics, 11, 103-114. https://doi.org/10.1017/s0267190500001987

Tarihoran, N., \& R. (2019). Exploring the Islamic culture in English for Islamic studies (EIS) classroom. Proceedings of the 4th ASEAN Conference on Psychology, Counselling, and Humanities (ACPCH 2018). https://doi.org/10.2991/acpch-18.2019.3

West, R. (1994). Needs analysis in language teaching. Language Teaching, 27(1), 1 19. https://doi.org/10.1017/s0261444800007527 